\title{
Pengaruh Kebiasaan Membaca di Media Online terhadap Penguasaan Kosakata Selama Pembelajaran Online
}

\author{
Penulis: \\ Dwi Puji Hastuti ${ }^{1}$ \\ Rizky Mirani Desi \\ Pratama $^{2}$ \\ Afiliasi: \\ Universitas Bina \\ Sarana Informatika ${ }^{1,2}$ \\ Email Koresponden: \\ dwi.dsu@bsi.ac.id \\ rizky.rrr@bsi.ac.id \\ Histori Naskah: \\ Diajukan: 29-07-2021 \\ Disetujui: 15-08-2021 \\ Dipublikasi: 17-08-2021

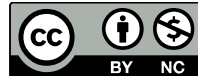 \\ This is an Creative Commons \\ License This work is licensed \\ under a Creative Commons \\ Attribution-NonCommercial 4.0 \\ International License
}

\begin{abstract}
Abstrak
Virus Covid-19 telah menyebar di Indonesia yang menyebabkan seluruh proses belajar mengajar berubah dari pembelajaran langsung menjadi pembelajaran online. Pembelajaran menggunakan media online menuntut siswa untuk meningkatkan kemandirian belajarnya terutama kebiasaan membaca dan penguasaan kosakata. Penelitian ini bertujuan untuk mengetahui pengaruh kebiasaan membaca di media online terhadap penguasaan kosakata selama pembelajaran online. Penelitian ini menggunakan data primer dan data sekunder yang diperoleh dari mahasiswa semester tiga program studi Bahasa Inggris di Universitas Bina Sarana Informatika. Metode yang digunakan adalah survei dengan menggunakan kuesioner sebanyak 20 pertanyaan pilihan ganda yang terdiri dari 10 pertanyaan mengenai variabel kebiasaan membaca dan 10 pertanyaan mengenai variabel penguasaan kosakata. Jumlah sampel dalam penelitian ini adalah 30 responden dengan menggunakan uji asumsi klasik, analisis regresi sederhana, analisis korelasi, koefisien determinasi dan pengujian hipotesis menggunakan uji-t dan uji-F dengan taraf signifikansi 5\%. Hasil penelitian menunjukkan bahwa kebiasaan membaca di media online berpengaruh positif dan signifikan terhadap penguasaan kosakata bahasa Inggris selama pembelajaran online, dengan demikian hipotesis diterima. Berdasarkan hasil tersebut membuktikan bahwa kebiasaan membaca di media online berpengaruh terhadap penguasaan kosakata. Hipotesis alternatif diterima dan hipotesis nol ditolak. Koefisien determinasi variabel kebiasaan membaca di media online melalui penguasaan kosakata sebesar $59,4 \%$ dan sisanya sebesar 40,6\% dipengaruhi oleh faktor lain.
\end{abstract}

Kata Kunci: Kebiasaan Membaca Media Online, Pembelajaran Online, Pengaruh, Penguasaan Kosakata

\section{Pendahuluan}

Bahasa memiliki keunggulan dalam perkembangan intelektual, sosial dan emosional manusia. Hal ini diharapkan dapat membantu manusia untuk saling berinteraksi dalam bentuk lisan dan tulisan. Pembelajaran bahasa dapat dikategorikan sebagai platform pembelajaran berbagai bahasa untuk dipelajari oleh berbagai kalangan dan mendukung keberhasilan proses pembelajaran. Salah satu bahasa terbesar di dunia yang digunakan sebagai bahasa komunikasi, baik lisan maupun tulisan, adalah bahasa Inggris. Kedudukan bahasa Inggris sebagai bahasa pemersatu semua negara di dunia semakin meningkat di era globalisasi ini karena bahasa tersebut digunakan di segala bidang, termasuk ilmu pengetahuan, teknologi, komunikasi, politik, ekonomi, perdagangan, perbankan, budaya, seni dan film. .

Sejak awal April 2020, Indonesia dihadapkan pada Virus Covid-19 yang menyebabkan seluruh proses belajar mengajar dialihkan menggunakan media online (Suharwoto, 2020). Berdasarkan kebijakan tersebut maka dilakukan upaya untuk menekan penyebaran virus Covid-19 yang sedang mewabah di 
masyarakat, oleh karena itu Kementerian Pendidikan dan Kebudayaan mengeluarkan kebijakan belajar dari rumah/online. Pembelajaran menggunakan media online menuntut siswa untuk meningkatkan kemandirian belajarnya terutama kebiasaan membaca dan penguasaan kosakata. Belajar dari Media Online dapat meningkatkan perbendaharaan kata, memotivasi siswa saat belajar (Mafulah \& Hariyanto, 2017). Terkait dengan kenyataan tersebut, ada beberapa siswa yang masih kesulitan memahami beberapa kosakata yang telah dipelajarinya, bahkan terkadang mereka lupa apa arti dari sebuah kata. Siswa saat ini enggan untuk menghafal beberapa kosakata penting dan hanya mengingat kosakata yang sering digunakan dalam kehidupan sehari-hari, hal ini menyebabkan kesulitan dalam belajar bahasa Inggris. Banyak siswa yang mengandalkan kamus online atau di berbagai website yang tersedia karena memudahkan siswa. Namun, hal itu tetap tidak menjamin kualitas perbendaharaan kata akan meningkat. Masih banyak siswa yang mengalami kesulitan dalam memahami kosakata dari setiap bacaan dan ucapan. Keterbatasan waktu dan akses bahan bacaan membuat siswa harus mengembangkan kebiasaan membaca literasi bahasa Inggris. Hal ini terkait dengan kebiasaan membaca siswa yang biasanya lebih mudah memahami isi bacaan secara langsung ketika berhadapan dengan guru. Berdasarkan hal tersebut, penulis memfokuskan pada pengaruh kebiasaan membaca di media online melalui penguasaan kosakata selama pembelajaran online.

\section{Studi Literatur}

Ada tiga komponen penting dalam belajar bahasa Inggris yang harus dipelajari dengan benar, yaitu kosakata, tata bahasa, dan pengucapan (Sugiharti \& Riftina, 2019). Penguasaan kosa kata merupakan hal wajib dalam pembelajaran bahasa. Tanpa penguasaan kosakata, akan sulit memahami isi bacaan atau teks lisan. Terkadang, bahasa sehari-hari yang biasa digunakan memiliki arti yang berbeda tergantung pada situasi dan maknanya. Kurangnya perbendaharaan kata dapat menimbulkan kesalahpahaman dan membuat komunikasi kurang efektif dalam mengungkapkan semua ide baik secara tertulis maupun lisan (Lestari, 2012). Kosakata merupakan dasar bagi seseorang untuk dapat berbicara, menulis bahkan mendengarkan. Penguasaan kosakata merupakan hal dasar yang dibutuhkan seseorang untuk menguasai pengetahuan suatu bahasa, khususnya dalam pembelajaran bahasa Inggris. Penguasaan kosakata merupakan kegiatan memahami suatu kata dengan cara belajar, mengingat, sehingga mudah digunakan dalam kegiatan sehari-hari sekaligus sebagai dasar pembelajaran bahasa. (Hastuti, 2020). Semua tahapan pembelajaran membutuhkan penguasaan kosa kata demi tercapainya bahasa Inggris dengan baik meskipun tidak mudah untuk memiliki penguasaan kosa kata yang baik jika pembelajar tidak mengetahui tingkat kosa kata mereka. (Fitriani, Nasir, Pertiwi, \& Fajrina, 2019).

Membaca adalah suatu kegiatan yang mempelajari banyak hal untuk memperoleh informasi yang terkandung dalam bacaan. Pada hakikatnya membaca dapat membuat orang mudah menerima informasi baik masa lalu maupun masa kini. Terkadang kendala dalam banyak kesempatan adalah kemalasan dalam membaca, padahal hal tersebut dapat membuat manusia mengalami kekurangan dalam berita dan informasi, terutama seperti teknologi yang berkembang saat ini hingga nanti. Kebiasaan membaca merupakan salah satu hal penting dalam membangun budaya membaca bagi setiap siswa di dunia pendidikan. Kebiasaan membaca diartikan sebagai tindakan yang secara mandiri menyusun konsep memahami suatu teks (Khalisa, 2018). Membaca dapat menjadi penghubung antara manusia, ilmu pengetahuan, dan ilmu pengetahuan, baik klasik maupun modern (Haryadi, 2020). Ada banyak manfaat dari kebiasaan membaca seperti yang diungkapkan oleh jika seseorang memiliki kebiasaan membaca informasi lebih banyak akan diperoleh maka mereka dapat mengetahui segala sesuatu yang terjadi baik di masa lalu, sekarang dan masa depan. (Sauturrasik, 2015). Membaca bisa menjadi cara yang menarik antara pembaca dan penulis yang terikat dengan membaca (Boyoh, 2018). Jika siswa di Indonesia masih memiliki kebiasaan membaca yang buruk, maka akan sulit bagi mereka untuk memperoleh informasi dan pengetahuan yang tepat untuk mendukung proses belajar mengajar. (Fadhillah, 2019). 
Pada penelitian sebelumnya, salah satu hasil penelitian pada variabel tersebut adalah terdapat pengaruh yang signifikan antara penguasaan kosakata dengan kemampuan membaca pemahaman, dengan pengaruh sebesar 50,6\% (Rofiq, 2020). Berdasarkan penelitian lain, bagaimanapun variabel yang berbeda, tidak ada pengaruh yang signifikan antara kebiasaan membaca terhadap prestasi belajar karena nilai regresinya adalah 0,304. Kemudian dalam penelitian lain disebutkan modernisasi teknologi membuat orang lebih memilih media membaca online daripada versi cetak karena banyak orang menggunakan gadget setiap hari (Tanjung, Ridwan, \& Gultom, 2017). Partisipasi aktif dalam mengembangkan kebiasaan membaca dapat membawa peningkatan yang baik tidak hanya sebagai kebiasaan juga sebagai budaya. Kebiasaan membaca dapat diakses dengan mudah dengan cara diklik, dibaca, dibagikan, didiskusikan, disimpan, atau diunduh tanpa mengacu pada jumlah buku yang dibaca orang (Kurniasih, 2016). Menurut penelitian AC Nielsen pada Agustus, pembaca media online digital lebih banyak daripada media cetak. Disebutkan, jumlah pembaca media online mencapai 6 (enam) juta orang sedangkan pembaca media cetak hanya 4,5 juta orang (Ekarina, 2020).

\section{Metode Penelitian}

Penelitian ini menggunakan pendekatan kuantitatif yang terdiri dari variabel X (kebiasaan membaca) sebagai variabel bebas dan variabel $\mathrm{Y}$ (penguasaan kosakata) sebagai variabel terikat. Metode yang digunakan adalah survey, penulis menggunakan kuesioner yang terdiri dari 20 pertanyaan pilihan ganda. Dalam penelitian ini adalah mahasiswa semester tiga program studi Bahasa Inggris di Universitas Bina Sarana Informatika. Populasi adalah wilayah generalisasi yang terdiri dari objek-objek yang mempunyai kualitas dan karakteristik tertentu yang kemudian diterapkan oleh peneliti untuk dipelajari dan kemudian ditarik kesimpulannya (Sugiyono, 2013). Populasi dan sampel dalam penelitian ini adalah 30 responden. Jika subjek kurang dari 100, semua diambil. sehingga penelitian ini merupakan penelitian populasi, dan jika jumlah subyeknya banyak dapat diambil antara 10-15\% atau 20-25\% atau lebih. (Arikunto, 2006). Teknik pengumpulan data untuk variabel $X$ (kebiasaan membaca) menggunakan 10 pernyataan dan untuk variabel Y (penguasaan kosa kata) menggunakan 10 pertanyaan, dimana setiap data diolah menggunakan SPSS 22.

Dalam menganalisis instrumen penelitian, penelitian ini menggunakan uji validitas terlebih dahulu, untuk mengetahui valid atau tidaknya suatu instrumen penelitian. Jika instrumen penelitian menunjukkan hasil yang benar maka dikatakan valid, tetapi jika instrumen penelitian menunjukkan hasil di bawah rata-rata maka dikatakan tidak valid. Uji reliabilitas tidak luput dari penelitian ini. Hal ini dilakukan untuk memastikan bahwa instrumen penelitian yang digunakan reliabel dan baik. Analisis yang digunakan dalam penelitian ini adalah analisis regresi linier sederhana. Tujuan dari uji regresi ini adalah untuk mengetahui pengaruh hubungan antara kedua variabel.

\section{Hasil}

Setelah penelitian dilakukan dengan menyebarkan angket pernyataan kepada 30 responden, kemudian diteliti satu persatu dan diberikan penilaian sesuai jawaban responden. Skor yang diperoleh dari penilaian angket kebiasaan membaca adalah skor terendah 16, skor tertinggi 48, skor rata-rata 32,97, median 33,00, modus 32 dan standar deviasi 8,011. Nilai ini diperoleh dari pengisian kuesioner penelitian yang memberikan informasi sebagai berikut: 5 (Sangat Setuju), 4 (setuju), 3 (cukup setuju), 2 (tidak setuju), dan 1 (sangat tidak setuju). Skor yang diperoleh dari penilaian angket untuk kategori penguasaan kosakata adalah skor terendah 1 , skor tertinggi 10 , skor rata-rata 7,37, skor median 8,00, skor mode 8 , dan standar deviasi 1,974. Nilai didapat dari hasil jawaban peserta, jika benar mendapat nilai 1 poin, jika salah mendapat nilai 0 poin. 
Edu Cendikia: Jurnal Ilmiah Kependidikan

Volume : 1 | Nomor 2 | Agustus 2021 | E-ISSN : 2798-365X | DOI: doi.org/educendikia.v1n2.1040

Table 1. Hasil Perhitungan Linear Regresi Sederhana

\begin{tabular}{|c|c|c|c|c|c|}
\hline \multicolumn{6}{|c|}{ Coefficients $^{\mathrm{a}}$} \\
\hline \multirow[t]{2}{*}{ Model } & $\begin{array}{r}\text { Uns } \\
\mathrm{C}\end{array}$ & $\begin{array}{l}\text { ardized } \\
\text { ients }\end{array}$ & $\begin{array}{l}\text { Standardized } \\
\text { Coefficients }\end{array}$ & $\mathrm{t}$ & Sig. \\
\hline & B & Std. Error & Beta & & \\
\hline (Constant) & 1,107 & 1,006 & & 1,101 & ,280 \\
\hline Reading Habit & , 190 & ,030 & ,771 & 6,400 & 000 \\
\hline
\end{tabular}

a. Dependent Variable : Penguasaan Kosakata

Table 2. Hasil Perhitungan Uji Hipotesis

\begin{tabular}{lrrrrr}
\multicolumn{7}{c}{ ANOVA $^{\text {a }}$} \\
& $\begin{array}{l}\text { Sum of } \\
\text { Squares }\end{array}$ & Df & Mean Square & F & Sig. \\
\hline Regression & 67,098 & 1 & 67,098 & 40,960 &, $000^{\mathrm{b}}$ \\
\hline Residual & 45,868 & 28 & 1,638 & & \\
\hline Total & 112,967 & 29 & & & \\
\hline
\end{tabular}

a. Dependent Variable : Penguasaan Kosakata

b. Predictors: (Constant), Kebiasaan Membaca

Tabel 3. Hasil Perhitungan Koefisien Determinasi

\begin{tabular}{ccccc}
\hline \multicolumn{5}{c}{ Model Summary } \\
\hline Model & $\mathrm{R}$ & R Square & $\begin{array}{c}\text { Adjusted R } \\
\text { Square }\end{array}$ & Std. Error of the Estimate \\
\hline 1 &, $771^{\mathrm{a}}$ &, 594 &, 579 & 1,280 \\
\hline
\end{tabular}

a. Predictors: (Constant), Kebiasaan Membaca

\section{Pembahasan}

Dari hasil pengujian di atas, didapatkan bahwa persamaan regresi linier sederhana adalah:

$\mathrm{Y}=\mathrm{a}+\mathrm{bX}$

$\mathrm{Y}=1.107+0.190 \mathrm{X}$

Berdasarkan tabel 1 diperoleh nilai konstanta sebesar 1,107 sedangkan nilai kebiasaan membaca sebesar 0,190 . Hal tersebut berpengaruh positif terhadap penguasaan kosakata $(Y)$ sehingga persamaan regresinya adalah $\mathrm{Y}=1.107+0.190$. Hal ini menunjukkan bahwa kebiasaan membaca $(\mathrm{X})$ berpengaruh positif terhadap penguasaan kosakata (Y). Jika variabel kebiasaan membaca meningkat maka akan menyebabkan peningkatan nilai penguasaan kosakata sebesar 0,190 yang berarti 19\%. Kebiasaan membaca diartikan sebagai tindakan yang secara mandiri menyusun konsep memahami sebuah teks (Khalisa, 2018).

Berdasarkan tabel 2 hasil uji ANOVA diatas diketahui nilai $\mathrm{F}$ hitung $=$ 40,960 dengan taraf signifikansi $0,000<0,05$. Regresi dapat digunakan untuk memprediksi variabel partisipasi atau dengan kata lain ada pengaruh variabel kebiasaan membaca $(\mathrm{X})$ terhadap penguasaan kosakata (Y). Tabel 2 menyatakan nilai ' $F$ ' yang diperoleh yaitu df 28 dengan taraf signifikansi 5\% diperoleh $\mathrm{F}$ tabel sebesar 4,20. $\mathrm{F}$ hitung sebesar 40,960 maka F hitung lebih besar dari F tabel. Oleh karena itu, hipotesis alternatif diterima dan 
hipotesis nol ditolak. Hal ini membuktikan bahwa terdapat pengaruh positif yang signifikan antara variabel kebiasaan membaca (X) terhadap variabel penguasaan kosakata (Y).

Berdasarkan tabel 3 di atas, hasil analisis yang diperoleh adalah hubungan antara variabel bebas (kebiasaan membaca) dengan variabel terikat (penguasaan kosakata) yang memiliki nilai $\mathrm{R}$ Square sebesar 0,594 yang berarti 59,4\% penguasaan kosakata dipengaruhi oleh kebiasaan membaca, sedangkan sisanya sebesar 40,6\% dipengaruhi oleh variabel lain yang tidak dijelaskan dalam penelitian ini.

Penelitian ini dilakukan di Jurusan Bahasa Inggris Universitas Bina Sarana Informatika. Peneliti tertarik untuk meneliti pengaruh kebiasaan membaca media online terhadap penguasaan kosakata selama pembelajaran online pada mahasiswa D-III (diploma-tiga) Bahasa Inggris Universitas Bina Sarana Informatika. Penulis ingin mengetahui apakah kebiasaan membaca media online berpengaruh besar terhadap penguasaan kosakata siswa selama pembelajaran online. Tidak mudah menghadapi situasi Covid-19, ketika semuanya serba ketat dan siswa harus menghadapi pembelajaran online secara individual. Responden yang mengikuti penelitian ini berjumlah 30 orang. Penelitian dilakukan dengan menyebarkan kuesioner kepada angkatan 2019. Berdasarkan hasil penelitian, pengaruh kebiasaan membaca terhadap penguasaan kosakata cukup tinggi mengingat hasilnya adalah 59,4\%. Jika variabel kebiasaan membaca meningkat maka akan menyebabkan peningkatan nilai penguasaan kosakata sebesar 0,190 yaitu $19 \%$.

\section{Kesimpulan}

Kebiasaan membaca dan penguasaan kosakata saling mempengaruhi selama pembelajaran online. Berdasarkan hasil hipotesis alternatif diterima dan hipotesis nol ditolak, hal ini terbukti memiliki persentase keefektifan $59,4 \%$. Sebagian besar responden merasa lebih mudah membaca media online daripada buku. Responden tidak perlu membawa buku asli, hanya membawa gadget dan mudah diakses dimana-mana. Hal ini juga relevan dengan penguasaan kosakata, responden merasa nyaman dan fleksibel.

\section{Referensi}

Boyoh, F. H. (2018). PENGARUH KEBIASAAN MEMBACA DAN PENGUASAAN KOSAKATA TERHADAP KEMAMPUAN BERBICARA BAHASA INGGRIS. Inference: Journal of English Language Teaching, 1(1), 14-21. Retrieved from https://journal.lppmunindra.ac.id/index.php/inference/article/view/3812

Ekarina. (2020). Transformasi Bisnis Media di Era Digital Terus Bergulir. Retrieved from katadata.co.id website: https://katadata.co.id/ekarina/brand/5fcfc332efab0/transformasibisnis-media-di-era-digital-terus-bergulir

Fadhillah, D. (2019). PENGARUH KEBIASAAN MEMBACA TERHADAP KECERDASAN LINGUISTIK PADA SISWA KELAS II SDN GEBANG RAYA KOTA TANGERANG. Lingua Rima, 8(2), 33-42. https://doi.org/http://dx.doi.org/10.31000/lgrm.v8i2.1786

Fitriani, S. S., Nasir, C., Pertiwi, H. I., \& Fajrina, D. (2019). THE STUDY ON VOCABULARY MASTERY AND VOCABULARY LEARNING STRATEGIES EMPLOYED BY. English Education International Conference, 2, 61-65. Retrieved from http://jurnal.unsyiah.ac.id/EEIC/article/view/14943

Haryadi, R. N. (2020). KEMAMPUAN BERBICARA BAHASA INGGRIS SMA NEGERI 99 JAKARTA masih rendah . Jika seseorang mempunyai. Jurnal Bina Mandiri, 1(02), 14-30. Retrieved

from https://jurnal.binamandiri.ac.id/index.php/jmbk/citationstylelanguage/get/acs- 
nano? submissionId=15\&publicationId=37

Hastuti, D. P. (2020). Influence of Reading Ability and Vocabulary Mastery on Writing Skills Descriptive Text. ANGLO-SAXON: Jurnal Ilmiah Program Studi Pendidikan Bahasa Inggris, 11(1), 48. https://doi.org/10.33373/as.v11i1.2424

Khalisa, N. (2018). THE CORRELATION BETWEEN STUDENTS' READING HABIT AND THEIR WRITING ABILITY (Ar-Raniry State Islamic University). Retrieved from repository.ar-rainy.ac.id

Kurniasih, N. (2016). Reading Habit in Digital Era : Indonesia People do not Like Reading, is it True? Worldcultureforum-Bali. Retrieved from https://worldcultureforum-bali.org/readinghabit-in-digital-era-indonesian-people-do-not-like-reading/

Lestari, I. Y. (2012). Upaya Peningkatan Penguasaan Kosakata Bahasa Inggris Anak Melalui Media Kartu Gambar (Flash Card) Pada Kelompok B di RA Barokah Klodran Karanganyar Tahun Pelajaran 2011/2012 (Universitas Muhammadiyah Surakarta). Retrieved from eprints.ums.ac.id

Mafulah, S., \& Hariyanto, F. A. (2017). The Effectiveness of Online Media in Improving Vocabulary of English Education Department Student. VOK @Sindo, 5(1), 21-35. Retrieved from https://vokasindo.ub.ac.id/index.php/vokasindo/article/view/34/pdf

Rofiq, F. A. (2020). Pengaruh Kebiasaan Membaca Dan Penguasaan Kosakata Terhadap Kemampuan Membaca Pemahaman Pada Siswa Kelas V SD Se-Gugus Dewi Sartika Kecamatan Dukuhwaru Kabupaten Tegal (Universitas Negeri Semarang). Retrieved from http://mpoc.org.my/malaysian-palm-oil-industry/

Sauturrasik. (2015). Korelasi Antara Kebiasaan Membaca Dengan Kemampuan Membaca Pemahaman Siswa Kelas XI IPA SMAN 1 Ambunten. Jurnal Lentera Sains (Lensa), 5(1), 25-34. https://doi.org/https://doi.org/10.24929/fkip.v5i1.243

Sugiharti, R. E., \& Riftina, Y. (2019). Upaya Meningkatkan Penguasaan Kosakata Bahasa Inggris melalui Model Scramble pada Siswa Kelas 4 SDN Jatimulya 04 Tambun Selatan. Indonesian Journal of Primary 14. https://doi.org/10.17509/ijpe.v2i2.15096

Suharwoto, G. (2020). Pembelajaran Online di Tengah Pandemi Covid-19, Tantangan yang Mendewasakan. Retrieved from Times Indonesia website: https://www.timesindonesia.co.id/read/news/261667/pembelajaran-online-di-tengahpandemi-covid19-tantangan-yang-mendewasakan

Tanjung, F., Ridwan, R., \& Gultom, U. (2017). Reading Habits in Digital Era: a Research on the Students in Borneo University. LLT Journal: A Journal on Language and Language Teaching, 20(2), 147-157. https://doi.org/10.24071/1lt.2017.200209 